
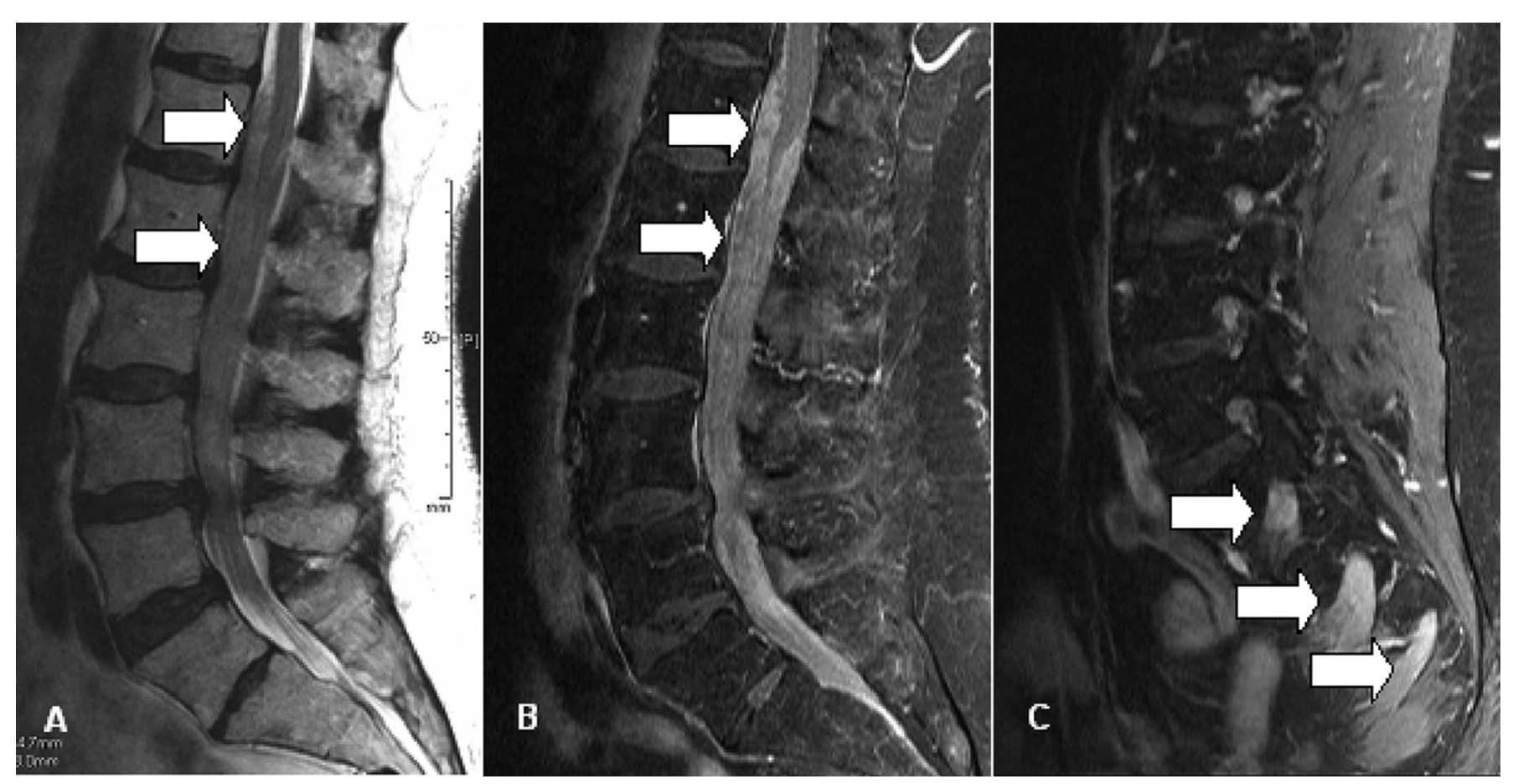

Figure. Sagittal (A through $C$ ) and parasagittal MR slices of the lumbar spine in a patient with chronic inflammatory demyelinating polyradiculoneuropathy. (A) T2-weighted image, showing lack of regular fluid-isointense signal, due to swollen cauda equina fibers (arrows). (B) Corresponding T1-weighted, fat-saturated image. Diffuse cauda equina enhancement (arrows) is depicted, indicating inflammation. (C) Parasagittal T1-weighted, fat-saturated image. Enlarged and enhancing root fibers are shown, exiting the neuroforamen (arrows).

\section{CIDP-induced spinal canal obliteration presenting as lumbar spinal stenosis}

Gerd Diederichs, MD; Jan Hoffmann, MD; and Randolf Klingebiel, MD, Berlin, Germany

A 59-year-old woman with chronic inflammatory demyelinating polyradiculoneuropathy (CIDP) in long-lasting remission presented with symptoms of lumbar spinal stenosis. Weakness in the lower limbs as well as hypesthesia and decreased sense of vibration in the L5/S1 segment were noted.

MRI of the spine (figure) revealed lumbar spinal canal stenosis due to pronounced enlargement of cauda equina fibers and bilat-

Disclosure: The authors report no conflicts of interest.

Address correspondence and reprint requests to Dr. Gerd Diederichs, Charité-Universitätsmedizin Berlin, Campus Charité Mitte, Charitéplatz 1, 10117 Berlin, Germany; e-mail: gerd.diederichs@charite.de eral thickening of the lumbar nerve roots. Fat suppressed postcontrast T1-weighted images showed nerve root and pial enhancement as reported previously. ${ }^{1}$

The diagnosis of CIDP was confirmed by characteristic findings in electrophysiologic as well as CSF studies. ${ }^{2}$ Electrophysiologic findings included abnormal conduction velocity, prolonged F-wave latencies, and partial conduction block. CSF studies depicted an elevated CSF protein concentration $(84.6 \mathrm{mg} / \mathrm{dL})$ without pleocytosis.

The patient was treated with IV corticosteroids and rapidly responded with complete remission of the radicular pain and major improvement of the hypesthesia.

1. Goldstein JM, Parks BJ, Mayer PL, Kim JH, Sze G, Miller RG. Nerve root hypertrophy as the cause of lumbar stenosis in chronic inflammatory demyelinating polyradiculoneuropathy. Muscle Nerve 1996;19:892896.

2. Saperstein DS, Katz JS, Amato AA, Barohn RJ. Clinical spectrum of chronic acquired demyelinating polyneuropathies. Muscle Nerve 2001; 24:311-324. 


\section{Neurology}

\section{CIDP-induced spinal canal obliteration presenting as lumbar spinal stenosis Gerd Diederichs, Jan Hoffmann and Randolf Klingebiel \\ Neurology 2007;68;701 \\ DOI 10.1212/01.wnl.0000256341.60996.ec}

This information is current as of February 26, 2007

\author{
Updated Information \& \\ Services \\ Supplementary Material \\ References \\ Permissions \& Licensing \\ Reprints
}

including high resolution figures, can be found at: http://n.neurology.org/content/68/9/701.full

Supplementary material can be found at: http://n.neurology.org/content/suppl/2007/11/08/68.9.701.DC1

This article cites 2 articles, 0 of which you can access for free at: http://n.neurology.org/content/68/9/701.full\#ref-list-1

Information about reproducing this article in parts (figures,tables) or in its entirety can be found online at:

http://www.neurology.org/about/about_the_journal\#permissions

Information about ordering reprints can be found online:

http://n.neurology.org/subscribers/advertise

Neurology ${ }^{\circledR}$ is the official journal of the American Academy of Neurology. Published continuously since 1951, it is now a weekly with 48 issues per year. Copyright . All rights reserved. Print ISSN: 0028-3878. Online ISSN: 1526-632X.

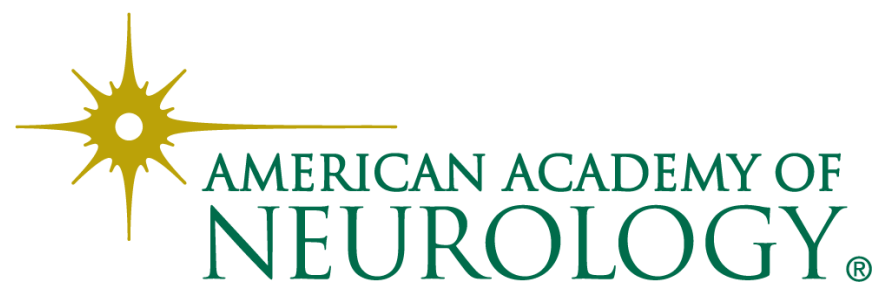

